\title{
Histopathology and Wound Healing in Oxytetracycline Treated Oreochromis niloticus (L.) Against Aeromonas hydrophila Intramuscular Challenge
}

\author{
Julinta RB ${ }^{1 *}$, Abraham TJ', Anwesha Roy ${ }^{1}$, Jasmine Singha', Gadadhar Dash'1, NageshTS ${ }^{2}$ and Patil PK $^{3}$
}

${ }^{1}$ Department of Aquatic Animal Health, Faculty of Fishery Sciences, West Bengal University of Animal and Fishery Sciences, Chakgaria, Kolkata, West Bengal, India ${ }^{2}$ Department of Fisheries Resource Management, Faculty of Fishery Sciences, West Bengal University of Animal and Fishery Sciences, Chakgaria, Kolkata, West Bengal, India ${ }^{3}$ Central Institute of Brackishwater Aquaculture, Indian Council of Agricultural Research, Raja Annamalai Puram, Chennai, Tamil Nadu, India

\begin{abstract}
Antibiotics are very important tools for the control of fish bacterial diseases. Yet, there are strict regulations controlling the use of antibiotics in aquaculture. This study assessed the efficacy oxytetracycline dihydrate (OTC) at a dose of $2 \mathrm{~g}, 4 \mathrm{~g}, 6 \mathrm{~g}$ and $8 \mathrm{~g} / 100$ pounds fish/day against Aeromonas hydrophila challenge in Nile tilapia Oreochromis niloticus as well as the histopathological alterations in kidney and muscle, and wound healing. The commercial pellet feed was top dressed with OTC using $5 \mathrm{ml}$ vegetable oil as a binder. The fish were injected intramuscularly with $A$. hydrophila at $\approx 1 \times 10^{8} \mathrm{cells} /$ fish and then fed OTC feeds at $2 \%$ of their body weight for 10 days. The fish fed with $8 \mathrm{~g}$ OTC/100 pounds fish/day recorded the lowest mortality (3.33\%). The untreated fish recorded $8.33 \%$ mortality. Histologically, the kidney tissues of $O$. niloticus exhibited nephropathy and glomerulopathy. The kidney of OTC fed groups had improved organization of nephritic tubules and glomerulus. The muscle tissues exhibited haemocyte infiltration with mild necrosis initially, followed by melanization and disrupted muscle bundles. The results demonstrated that the OTC treatment for 10 days could bring out improved functioning of fish kidneys that carry infectious agents. Within 3 days of OTC therapy, tissue reddening and inflammation subsided with the formation of black scar. Full recovery of normal skin architecture was reached within 26-31 days post-injection. Based on the results, prudent use of 4-8 $\mathrm{g}$ OTC/100 pounds fish/day is recommended for the control of $A$. hydrophila infection in O. niloticus.
\end{abstract}

Keywords: Aeromonas hydrophila; Oreochromis niloticus; Oxytetracycline; Oral therapy; Nephropathy; Necrotic lesion

\section{Introduction}

The tilapias are freshwater fish that belong to the family Cichlidae, and they are exclusively associated with Africa and Middle East [1]. The Nile tilapia (Oreochromis niloticus L.) is one of the first fish species to be cultured in the world. Illustrations from Egyptian tombs suggested that the Nile tilapias had been cultured more than 4,000 years ago [2]. In 2010 , more than $73 \%$ of total tilapia production were represented by $O$. niloticus [3]. The farmed tilapia production statistics from 135 countries and territories on all continents are available currently [4]. Considering the demand for more fish, it has become an important species for aquaculture in India [5]. Initially, tilapias were considered to be more resistant to microbial diseases. But, in recent times tilapias have been found to be susceptible to various diseases. Bacterial infections are the most serious problem in tilapia production causing $80 \%$ of fish mortalities [2,6-7]. Aeromonas hydrophila is considered as a persuasive pathogen that causes mortalities in tilapia and other freshwater fish $[8,9]$. Fish exposed to poor water quality such as high nitrite levels, low levels of dissolved oxygen, or high levels of carbon dioxide are more susceptible to infection by bacterial pathogens [2].

Most bacterial infections can be treated effectively with antibiotics. However, the farmers use a variety of aquadrugs for the control of fish diseases [10]. Treatment of A. hydrophila is currently limited to two antibiotics, Terramycin , an oxytetracycline (OTC), and Remet-30, a potentiated sulfonamide. Oxytetracycline is one of the USFDA (United States Food and Drug Administration) approved chemotherapeutic as an oral antibacterial to treat specific bacterial diseases in temperate and warm water finfish [11-13]. The preparation of medicated feed for use with fish intended for human consumption is, however, regulated by the FDA [13]. The stability of OTC in feed premixes has been evaluated and is well established at $>90 \%$ retained potency after 24 months of storage under ambient conditions [14]. Though the effectiveness and safety levels of the FDA approved antibiotics, including OTC on temperate fish have been established, such studies on fish species cultured in topical condition are not attempted. This study was, therefore, aimed at to evaluate the effectiveness of feeds containing different concentrations of OTC on Nile tilapia O. niloticus against A. hydrophila infection with particular reference to histopatological alterations in kidney and muscle, and wound healing.

\section{Materials and Methods}

\section{Bacterial strain}

The $\beta$-haemolytic and oxytetracycline sensitive bacterial strain Aeromonas hydrophila $\mathrm{BBT}_{4} \mathrm{~K}_{3}$ (NCBI accession number KY484791) used in this study was from the collections of the Department of Aquatic Animal Health, Faculty of Fishery Sciences, West Bengal University of Animal and Fishery Sciences, Kolkata, India. It was isolated from the kidney of haemorrhagic septicemic O. niloticus. The isolation, identification and preparation of bacterial cell suspension were as described in Abraham et al. [15].

\section{Feed top dressing}

As per the FDA standards [12], the medicated feeds for feeding

*Corresponding author: R. Beryl Julinta, Department of Aquatic Animal Health Faculty of Fishery Sciences, West Bengal University of Animal and Fishery Sciences, Chakgaria, Kolkata-700094, West Bengal, India, Tel: +91 98832 87694; E-mail: julintaa@gmail.com

Received June 03, 2017; Accepted June 28, 2017; Published June 30, 2017

Citation: Julinta RB, Abraham TJ, Roy A, Singha J, Dash G, et al. (2017) Histopathology and Wound Healing in Oxytetracycline Treated Oreochromis niloticus (L.) Against Aeromonas hydrophila Intramuscular Challenge. J Aquac Res Development 8: 488. doi: 10.4172/2155-9546.1000488

Copyright: $\odot 2017$ Julinta RB, et al. This is an open-access article distributed under the terms of the Creative Commons Attribution License, which permits unrestricted use, distribution, and reproduction in any medium, provided the original author and source are credited. 
the experimental fish at $2 \%$ of the body weight (BW) were prepared. In brief, the medicated feeds to feed fish at a dose of $2 \mathrm{~g}, 4 \mathrm{~g}, 6 \mathrm{~g}$ and $8 \mathrm{~g}$ OTC/100 pounds fish/day were prepared by mixing appropriate quantities of oxytetracycline dihydrate (HiMedia, India) in $5 \mathrm{ml}$ vegetable oil and then admixed with $1 \mathrm{~kg}$ basal feed. The feeds containing OTC were mixed thoroughly, air dried at room temperature for $24 \mathrm{~h}$, and stored separately in air tight plastic containers. Control feed was prepared as above without OTC. All feeds were prepared freshly and used immediately.

\section{Efficacy of OTC}

Plastic tanks of size L58 $\mathrm{cm} \times \mathrm{H} 45 \mathrm{~cm} \times \mathrm{B} 45 \mathrm{~cm}$, and healthy Oreochromis niloticus (L.) juveniles of $8.25 \pm 0.25 \mathrm{~cm}$ and $7.91 \pm$ $0.31 \mathrm{~g}$ were used for the experiments in triplicate. Thirty tilapias were introduced into each of the tank and fed with basal pellet feed containing $30 \%$ crude protein at $2 \%$ BW. About $50 \%$ water was exchanged, and waste feed and faeces were removed periodically. The water quality parameters were maintained optimally (Water temperature: $22.0-29.0^{\circ} \mathrm{C}$; $\mathrm{pH}: 8.0-8.7$; dissolved oxygen: 4.2-4.9 ppm; nitrate and ammonia: $<0.02 \mathrm{ppm}$ ). The experimental fish were divided into 7 groups, namely group 1) negative control (unchallenged and fed with basal feed), group 2) positive control (saline injected, unchallenged and fed with basal feed), group 3) $0 \mathrm{~g} \mathrm{OTC} / 100$ pounds fish/day, group 4) $2 \mathrm{~g}$ OTC/100 pounds fish/day, group 5) $4 \mathrm{~g}$ OTC/100 pounds fish/day, group 6) $6 \mathrm{~g}$ OTC/100 pounds fish/day, and group 7) $8 \mathrm{~g}$ OTC/100 pounds fish/day. After acclimatization for 5 days, the fish were injected intramuscularly at the base of the dorsal fin. Prior to challenge, the fish were starved for a day and anesthetized using clove oil at $50 \mu \mathrm{l} /$ litre water. The fish of groups 2-7 were injected intramuscularly with aliquots $\left(0.1 \mathrm{ml}\right.$ each) of $A$. hydrophila $\mathrm{BBT}_{4} \mathrm{~K}_{3}$ cell suspension at a predetermined dose of $1 \times 10^{8}$ cells/fish. After injection, the fish were transferred to the respective tanks. The fish of groups 1 and 2 were fed with basal feed and the group 3 was fed with control feed during the entire study period. The fish of groups 4, 5, 6 and 7 were fed with control feed during the pre-treatment (1-5 days) and disease progression (6-8 days) periods. During the treatment period for 10 days (9-18 days), they were fed with respective OTC feeds at $2 \%$ BW twice daily. During the post-treatment period for 21 days (19-39 days), the fish were fed with control feed. The unconsumed feed, if any, in each tank was removed daily, air dried and weighed carefully. Observations on feeding behaviour, behavioural changes, external signs of infections and mortality were recorded daily. Depending on the feed consumption, the feeding behavior of tilapia was rated using a scale ranging from 0 to 4 , i.e., 4) $100 \%$ feed consumption, 3) $75 \%$ feed consumption, 2) $50 \%$ feed consumption, 1) $25 \%$ feed consumption and 0 : No feed consumption.

\section{Histopathology}

The muscle and kidney samples of $A$. hydrophila $\mathrm{BBT}_{4} \mathrm{~K}_{3}$ challenged and subsequently OTC treated O. niloticus were fixed in Bouin's solution for $24 \mathrm{~h}$. The fixed samples were processed by standard techniques and embedded in paraffin wax. Thin $(5 \mu \mathrm{m})$ sections were prepared and stained with haematoxyline and eosin [16].

\section{Wound healing}

The wounds at the site of intramuscular injection were first digitally photographed during the treatment regime. Tissue damages were assessed using a score ranging from 0 to 6 , depending on the degree and extent of damage based on the scale proposed by Bernet et al. [17]. The extent of wound progression and healing was qualitatively classified as
0: undamaged; 2: mild damage; 4: moderate damage; 6: severe damage. Intermediate values were also considered.

\section{Statistical analysis}

The results of the experiment are expressed as mean \pm standard deviation and analyzed by one-way analysis of variance (ANOVA) using Microsoft excel version 2010 to test the significance of differences among the experimental fish groups. Comparison of mean values was done by Duncan's Multiple Range Test [18]. A probability level of 0.05 was used to find out the significance in all cases.

\section{Results}

\section{Efficacy of OTC therapies}

The mortalities and cumulative mortalities recorded during the treatment regime in A. hydrophila challenged and OTC fed O. niloticus juveniles are presented in Figures 1 and 2, respectively. During the disease progression period, i.e., on day $8,3.33-5.00 \%$ mortalities were noticed in treatment groups. At the end of 10 day OTC treatment, i.e., on day 18 , the mortalities observed in challenged and OTC fed groups were $3.33-6.66 \%$. The highest mortality (8.33\%) was observed in $A$. hydrophila challenged and control feed fed fish. Significant differences existed between the positive control (saline injected), and challenged and control feed fed as well as OTC fed $(2 \mathrm{~g}, 4 \mathrm{~g}$ and $6 \mathrm{~g}$ OTC/100 pounds fish/day) groups $(\mathrm{P}<0.05)$. Significant differences also existed among $0 \mathrm{~g}$ OTC/ 100 pounds fish/day group and the OTC feeds fed $(4 \mathrm{~g}$, $6 \mathrm{~g}$ and $8 \mathrm{~g}$ OTC/100 pounds fish/day) group $(\mathrm{P}<0.05)$. The difference in the mortality between $2 \mathrm{~g}$ and $8 \mathrm{~g}$ OTC/100 pounds fish/day groups was significant $(\mathrm{P}<0.05)$.

The rating of feeding behaviour of $A$. hydrophila challenged $O$. niloticus juveniles during the treatment regime is presented in Table 1. The feed intake of challenged and control feed fed tilapia was low till $18 \mathrm{dpi}$, which became normal subsequently. In OTC fed groups,

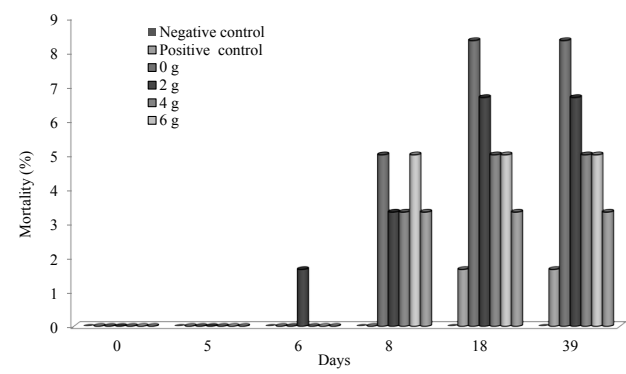

Figure 1: Mortalities in Oreochromis niloticus juveniles when challenged intramuscularly with Aeromonas hydrophila and subsequently fed oxytetracycline feeds (g OTC/100 pounds fish/day) for 10 days.

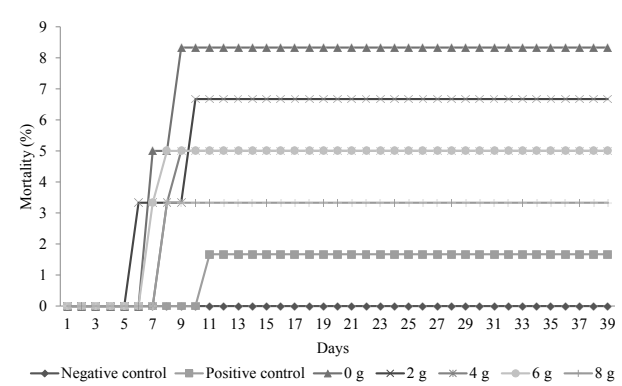

Figure 2: Cumulative mortalities in Oreochromis niloticus juveniles when challenged intramuscularly with Aeromonas hydrophila and subsequently fed oxytetracycline feeds (g OTC/100 pounds fish/day) for 10 days. 
Citation: Julinta RB, Abraham TJ, Roy A, Singha J, Dash G, et al. (2017) Histopathology and Wound Healing in Oxytetracycline Treated Oreochromis niloticus (L.) Against Aeromonas hydrophila Intramuscular Challenge. J Aquac Res Development 8: 488. doi: 10.4172/2155-9546.1000488

reduced feed intake was noted during the early OTC treatment period. The freshly dead fish were subjected to necropsy and bacteriology. Internally, discoloration and liquefaction of the internal organs, viz., kidney and liver were observed in the intramuscularly challenged fish. Bacterial inocula from the kidney of fresh dead fish on Rimler-Shotts agar yielded exclusive growth of yellow colour colonies at $35^{\circ} \mathrm{C}$ in 24-48 h. The standard biochemical test results confirmed Aeromonas infection (data not shown).

\section{Histopathology}

Histologically, the kidney tissues of unchallenged tilapia showed

\begin{tabular}{|c|c|c|c|c|}
\hline \multirow{2}{*}{ Treatments } & \multicolumn{2}{|c|}{ Feeding behaviour score\# in Mean \pm standard deviation } \\
\cline { 2 - 5 } & $\begin{array}{c}\text { Pre-treatment } \\
\text { (1-5 days) }\end{array}$ & $\begin{array}{c}\text { Disease } \\
\text { progression } \\
\text { (6-8 days) }\end{array}$ & $\begin{array}{c}\text { OTC } \\
\text { treatment } \\
\mathbf{( 9 - 1 8 ~ d a y s ) ~}\end{array}$ & $\begin{array}{c}\text { Post- } \\
\text { treatment } \\
(\mathbf{1 9 - 3 9} \text { days) }\end{array}$ \\
\hline $\begin{array}{c}\text { Negative } \\
\text { control }\end{array}$ & $4.00 \pm 0.00$ & $4.00 \pm 0.00$ & $4.00 \pm 0.00$ & $4.00 \pm 0.00$ \\
\hline 0 g OTC & $4.00 \pm 0.00$ & $3.64 \pm 0.67$ & $2.70 \pm 0.83$ & $4.00 \pm 0.00$ \\
\hline 2 g OTC $^{*}$ & $4.00 \pm 0.00$ & $3.64 \pm 0.67$ & $3.77 \pm 0.43$ & $4.00 \pm 0.00$ \\
\hline 4 g OTC $^{*}$ & $4.00 \pm 0.00$ & $3.64 \pm 0.67$ & $3.77 \pm 0.43$ & $4.00 \pm 0.00$ \\
\hline 6 g OTC $^{*}$ & $4.00 \pm 0.00$ & $3.68 \pm 0.57$ & $3.74 \pm 0.45$ & $4.00 \pm 0.00$ \\
\hline 8 g OTC $^{*}$ & $4.00 \pm 0.00$ & $3.76 \pm 0.54$ & $3.85 \pm 0.37$ & $4.00 \pm 0.00$ \\
\hline
\end{tabular}

OTC: oxytetracycline; *: Fish groups were fed with OTC at an appropriate dose/100 pounds fish/day for 10 days after challenging intramuscularly with Aeromonas hydrophila. Negative Control: Unchallenged, saline injected and fed basal feed. \#: Feeding behaviour scale: $4: 100 \%$ feed consumption, 3: $75 \%$ feed consumption, 2: $50 \%$ feed consumption, $1: 25 \%$ feed consumption and 0 : No feed consumption.

Table 1: Feeding behaviour of Oreochromis niloticus juveniles challenged with Aeromonas hydrophila and fed oxytetracycline (g OTC/100 pounds fish/day) at $2 \%$ of body weight for 10 days.

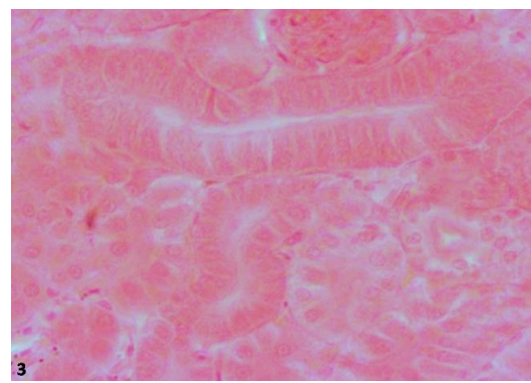

Figure 3: The normal histology of the kidney tissues of Oreochromis niloticus juveniles showing the typical structural organization of nephritic tubules with well-defined glomerulus, X200 H\&E staining.
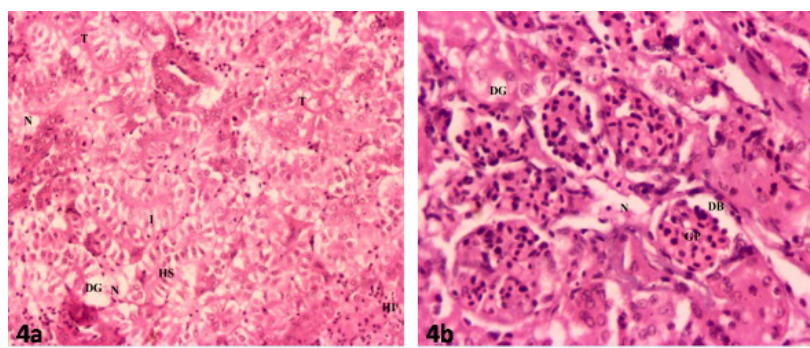

Figure 4: Histopathological changes in the kidney tissues of control feed (0 g OTC/100 pounds fish/day group) fed Oreochromis niloticus juveniles intramuscularly injected with Aeromonas hydrophila $\mathrm{BBT}_{4} \mathrm{~K}_{3}$ on $10^{\text {th }}$ day treatment showing (a) inflamed (I) nephritic tubules, haemocyte infiltration $(\mathrm{HI})$, hydropic swelling (HS) with necrotized areas $(\mathrm{N})$, degeneration of nephritic tubules (DG), deeply stained nucleus (DS) and thickening of nephritic tubule (T) X200 H\&E staining; (b) degeneration of nephritic tubules (DG), glomerulopathy (GP) with dilated Bowman's space (BS) and necrosis (N), X400 H\&E staining.

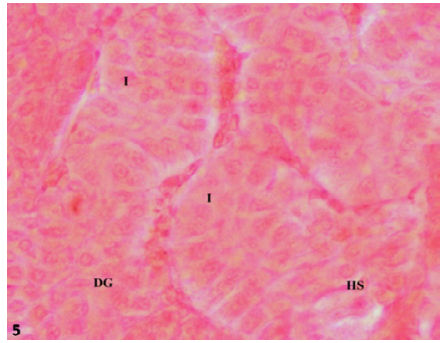

Figure 5: Histopathological changes in the kidney tissues of OTC fed $(8 \mathrm{~g}$ OTC/100 pounds fish/day group) Oreochromis niloticus juveniles intramuscularly injected with Aeromonas hydrophila BBT $\mathrm{K}_{3}$ on the $10^{\text {th }}$ day OTC treatment showing hydropic swelling (HS), inflammation (I) and degeneration of nephritic tubules (DG), X400 H\&E staining.

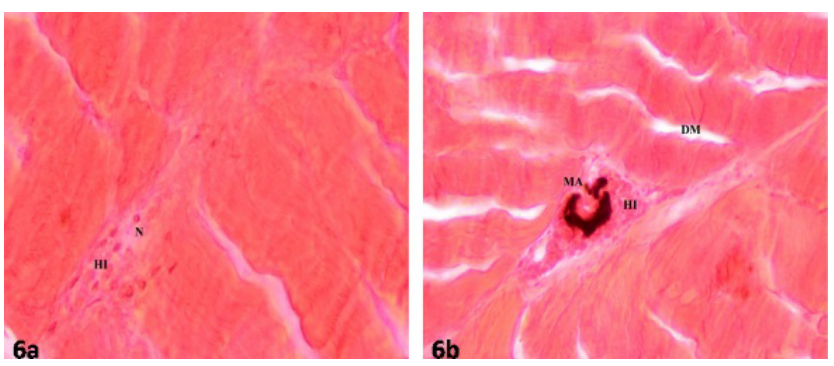

Figure 6: Histopathological changes in the muscle tissues of Oreochromis niloticus juveniles intramuscularly injected with Aeromonas hydrophila $\mathrm{BBT}_{4} \mathrm{~K}_{3}$ (a) on 2 day post-injection showing haemocyte infiltration $(\mathrm{HI})$ with mild necrosis (N), X200 H\&E staining; (b) on $10^{\text {th }}$ day OTC (8 g OTC/100 pounds fish/day) treatment showing melanized area (MA) with haemocyte infiltration $(\mathrm{HI})$ and disrupted muscle bundles (DM), X400 H\&E staining.

the typical structural organization of the nephritic tubules with well-organized glomerulus (Figure 3). While the kidney tissues of challenged and control feed fed $O$. niloticus juveniles recorded nephritic tubules inflammation, haemocyte infiltration, thickening of nephritic tubule, hydropic swelling with necrotized areas (Figure 4a), and glomerulopathy with dilated Bowman's space and degeneration of nephritic tubules (Figure $4 \mathrm{~b}$ ). The histopathological changes noticed in the kidney tissues of OTC ( $8 \mathrm{~g}$ OTC/100 pounds fish/day) fed $O$. niloticus on $10^{\text {th }}$ day OTC feeding were inflammation of nephritic tubules, glomerulus with no pathological changes and thin epithelial layer, hydropic swelling, degeneration of nephritic tubules (Figure 5). The muscle tissues of challenged O. niloticus on 2 dpi had haemocyte infiltration with mild necrosis (Figure 6a), while the OTC fed (8 g OTC/100 pounds fish/day) O. niloticus on $10^{\text {th }}$ day OTC feeding exhibited melanization and disrupted muscle bundles (Figure 6b).

\section{Wound healing}

The qualitative rating of wound progression and healing in $O$. niloticus challenged intramuscularly with $A$. hydrophila and fed OTC feed ( $8 \mathrm{~g}$ OTC/100 pounds fish/day group) for 10 days is depicted in Figure 7 . The challenged fish were weak and lethargic initially. Tissue reddening, inflammation and skin peeling at the site of injection, and open sub-epithelial wounds started to become obvious within 24 and $48 \mathrm{~h}$ of challenge with A. hydrophila, respectively. A membrane over the wound was observed on 3 day post-injection (dpi). Within 3 days of OTC therapy, the reddening and inflammation subsided with the formation of black scar in the ulcerated area. The areas surrounding the wound become very dark in 3-6 days of therapy. Though there were depressions at the site of injection, all wounds examined were closed within 9 days of wounding or 6 days of OTC therapy (dot). 
Disappearance of black scar, onset of dermal fibrous tissue re-growth and the development of skin at the ulcerated scar region were seen on $13 \mathrm{dpi}(10 \mathrm{dot})$. The epidermis gradually became thinner with the development of scales in the underlying tissues and appeared normal on 20 dpi (7 days after OTC therapy). Full recovery of normal skin architecture was reached within 26-31 dpi (Figure 8). The wounds of OTC fed groups healed faster than the control.

\section{Discussion}

Disease is a component of the overall welfare of fish [19]. A perusal of the literature revealed the use of a wide range of antibiotics in attempts to control bacterial diseases in aquaculture [9-11,13]. The dosage rate used in medicated feed may vary according to the specific antibiotic used, but usually the rate is based on a number of grams/100 pounds fish/day [13]. The experimental transmission route used in the present study was intramuscular injection, which was reportedly more replicable and efficient than the other methods [20]. In the present study $A$. hydrophila challenge caused fish mortalities only during the disease progression and early OTC treatment periods. Following OTC sensitive A. hydrophila challenge and oral therapy, a reduction in tilapia mortality with increasing OTC concentrations was observed. The results suggested that OTC has the potentiality to control $A$. hydrophila infection in Nile tilapia only at higher doses. The highest survival (96.67\%) was noted in $8 \mathrm{~g}$ OTC/100 pounds fish/day group,

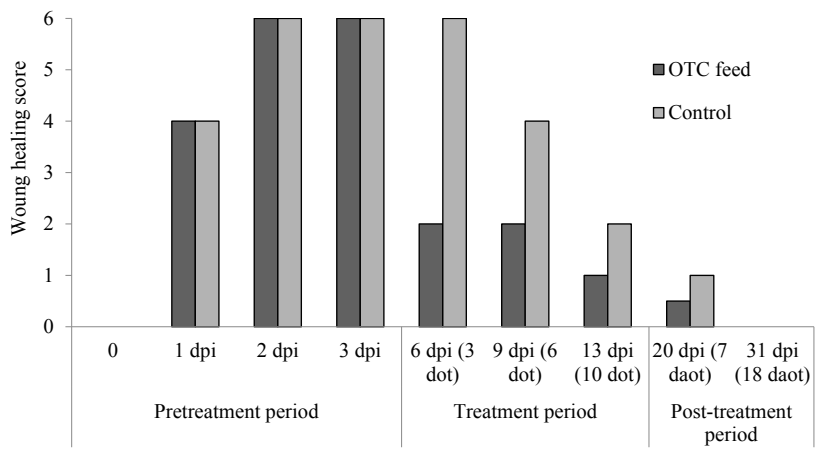

Figure 7: The qualitative rating of wound progression and healing in Aeromonas hydrophila challenged Oreochromis niloticus when fed with oxytetracycline (OTC) (8 g OTC/100 pounds fish/day) and control feeds during treatment regime.
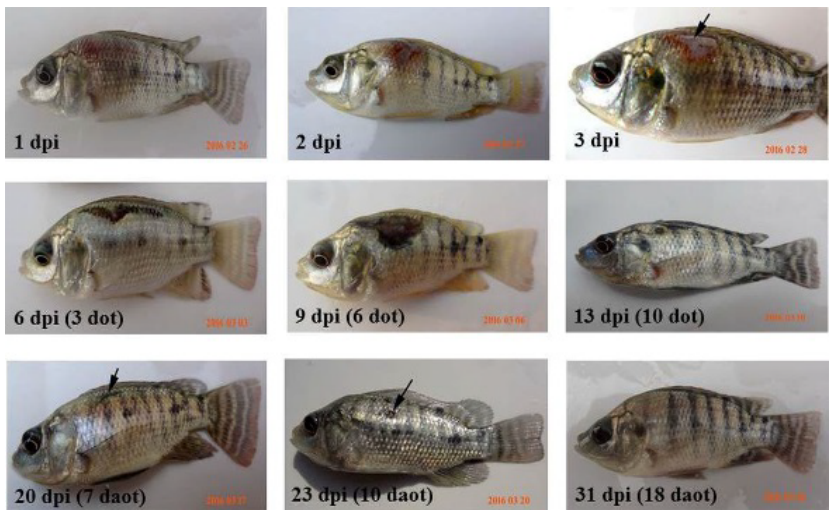

Figure 8: Digital images showing the wound progression and healing in Aeromonas hydrophila challenged, and oxytetracycline feed fed Oreochromis niloticus juveniles during the treatment regime. dpi: day post injection; dot: day OTC treatment; daot: day after OTC treatment. followed by $95 \%$ each in $4 \mathrm{~g}$ and $6 \mathrm{~g}$ OTC/100 pounds fish/day groups. Statistically, the dose of $2 \mathrm{~g}$ OTC/100 pounds fish/day was found to be ineffective. These results further suggested that the dose of 4-8 g $\mathrm{OTC} / 100$ pounds fish/day, equivalent to $2-4 \mathrm{~g}$ OTC/ $\mathrm{kg}$ feed, is ideally used to control $A$. hydrophila infection in Nile tilapia under tropical Indian condition. Our results provided supportive evidences to Plumb [6], who recommended a dose of 2-4 g OTC/ $\mathrm{kg}$ feed $(50-100 \mathrm{mg} / \mathrm{kg}$ fish) for 14 days for bacterial disease treatment. The present study, thus, demonstrated the effectiveness of OTC oral therapy in reducing the $A$. hydrophila induced mortalities in Nile tilapia, which was found to be dose-dependent.

Histopathology is a well-established tool to figure out the qualitative changes in the affected organs and the patterns of recovery. Histopathologically, the main worth mentioning lesions is located in the kidney [21] and, therefore, the kidney samples were examined for the qualitative tissue level changes. The muscle samples were also examined as the fish were challenged intramuscularly. In unchallenged control fish, normal structure and systematic arrangement of kidney tissues with well-defined glomerulus were observed histologically. On the other hand, the changes observed in the kidney tissues of $O$. niloticus challenged with $A$. hydrophila on $10^{\text {th }}$ day feeding with control feed and OTC feed (8 g OTC/100 pounds fish/day) during the treatment period were variable. The pathological changes observed in the kidney of $A$. hydrophila challenged and control feed fed O. niloticus are suggestive of nephropathy with severe cellular and tissue level alterations. The hydropic swelling, i.e., marked cell swelling of nephritic tubular epithelial cells is indicative of severe cellular oedema. Besides, there were glomerulopathy with dilated Bowman's space, necrotized areas, severe inflammation, degeneration and thickening of nephritic tubules, which are in accordance with the previous studies [22,23]. Though indeed there was inflammation, the 10 days OTC feeding controlled the tissue level changes in the kidney of $A$. hydrophila challenged $O$. niloticus, which exhibited glomerulus with no pathological changes, thin epithelial layer, and improved architecture and organization of nephritic tubules. The results demonstrated that the OTC treatment for 10 days could bring out improved functioning of fish kidneys that carry infectious agents. Nonetheless, several earlier studies demonstrated negative effects of OTC administration at high concentrations; for example, tissue damages in the kidneys when OTC was administered intramuscularly [21], congestion, severe fatty changes and vacuolations in the hepatocytes and periglomerular lymphocytic aggregation in the kidney of O. niloticus when fed with OTC at $100 \mathrm{mg} / \mathrm{kg}$ diet [24], diffuse cytoplasmic vacuolization of the renal duct epithelium in the kidney of C. carpio when fed OTC feed at $15 \mathrm{~g} / \mathrm{kg}$ live weight [25]. Necrosis was observed only in challenging and non-treated fish, while it was absent in unchallenged control fish as well as challenged and OTC treated fish. It is clear from the present study that the normal kidney tissue exhibited well-defined nephrons, which when challenged with $A$. hydrophila showed nephropathy and glomerulopathy and finally, when treated with OTC, the kidney tissue showed improvement in nephritic tubular organization.

Melanin containing macrophages within the epidermal layer plays an important role in the healing of the injected area [21]. The haemocyte infiltration with mild necrosis at the intramuscularly injected site of $O$. niloticus on $2 \mathrm{dpi}$ is an indication of a severe cellular and inflammatory reaction together with the disorganization of the muscular tissue, which seemed to be in agreement with the observations of Soler et al. [21]. The muscle tissue of A. hydrophila infected fish on the $10^{\text {th }}$ day OTC feeding showed melanized area as dermomuscular necrotic lesion at the site of injection, which conform the previous reports [26,27]. These 
Citation: Julinta RB, Abraham TJ, Roy A, Singha J, Dash G, et al. (2017) Histopathology and Wound Healing in Oxytetracycline Treated Oreochromis niloticus (L.) Against Aeromonas hydrophila Intramuscular Challenge. J Aquac Res Development 8: 488. doi: 10.4172/2155-9546.1000488

Page 5 of 6

melanized areas were identified as aggregates of cells containing dark pigments. The melanin within the dermis of tilapia indicated mature healing ulcer at the site of injection. All these histopathological findings suggested marked improvements in the kidney and muscle tissues of $A$. hydrophila infected O. niloticus up on OTC treatment. The reduction in bacterial population and its consequences may probably be the underlying mechanism for the beneficial effect of OTC as was observed with antibiotics [9].

The rate of wound progression and recovery in A. hydrophila challenged $O$. niloticus juveniles upon oral OTC therapy was also investigated in the present study. The tissue reddening, inflammation and formation of a membrane over the wound within $3 \mathrm{dpi}$ is an indication of initial protective reactions of fish to ward off the bacterial challenge. With OTC therapy, the reddening and inflammation were subsided relatively faster than control. The formation of black scar in the ulcerated area within 3 days of OTC therapy indicated the closure of the wound by the layers of epidermal cells. Darkened areas surrounding the wound in 3-6 days of therapy may be due to increased number of melanocytes, thereby, suggesting an increased melanocytes activity after the injury $[28,29]$. Within 6-10 days of OTC therapy, regeneration of muscle tissue with the closure of wounds, disappearance of black scar, onset of dermal fibrous tissue growth and the development of skin at the ulcerated scar region was obvious. The epidermis appeared normal with the development of scales in the underlying tissues after 7 days of completion of OTC therapy. Ohira et al. [30] also observed the growth of new scales with the size and characteristics of mature scales within a few weeks. The repair of dermal and muscle structure took much longer time in comparison with the epidermis. These results corroborate the findings of Ashley et al. [31], who described a temporal precedence of epidermal over dermal repair. Quilhac and Sire [32] also observed a rapid differentiation of the epidermal basal layer cells during the re-epithelialization process after wounding of a cichlid fish. The depression at the site of injection during the recovery period is an indication that the tissue re-growth or dermal repair had not reached steady state levels. Full recovery of normal skin architecture was reached within 26-31 dpi. Though the rate of wound healing was initially faster in OTC treated fish, the wounds were healed completely within 31 days even in untreated survivors. The results confirmed that the degree of wound healing was promoted by OTC feed, which was more prominent during the treatment period. Unlike mammals, no scar or scab was left behind on the wounded region, thereby representing a more advanced healing progression in teleost.

\section{Conclusion}

In general, concerns about the consequences of antibiotic use on public health have encouraged the development of strict regulations controlling the use of antibiotics and have led to only a few antibiotics being licensed for use in aquaculture. In this context, the present study demonstrated the effectiveness of dose-dependent OTC oral therapy in reducing the A. hydrophila induced mortalities in Nile tilapia and improving the kidney tissue architecture. The results suggested the prudent use of 4-8 $\mathrm{g}$ OTC/100 pounds fish/day at $2 \%$ body weight ration to control $A$. hydrophila infection in Nile tilapia under tropical Indian conditions. Since OTC is one of the FDA approved antibiotics for treating bacterial diseases of temperate and warm water finfish, responsible use of OTC as outlined by FAO $[11,13]$ is recommended for the control of Aeromonas infection in Nile tilapia. Further, our results would provide the baseline data on the efficacy of OTC to the policy makers and regulatory authorities of Indian and global aquaculture.

\section{Conflict of Interest}

The authors declare that there is no conflict of interest.

\section{Acknowledgements}

The research work was supported by the Indian Council of Agricultural Research, Government of India, New Delhi under the All India Network Project on Fish Health (Grant F. No. CIBA/AINP-FH/2015-16 dated 02.06.2015). The authors thank the Vice-Chancellor, West Bengal University of Animal and Fishery Sciences, Kolkata for providing necessary infrastructure facility to carry out the work.

\section{References}

1. Trewaves E (1983) Tilapia fishes of the Genera Sarotherodon, Oreochromis. Danakilia. British Museum of Natural History.

2. Amal MNA, Zamri-Saad M (2011) Streptococcosis in tilapia (Oreochromis niloticus): A review. Pertanika Journal of Tropical Agricultural Science 34: 195-206.

3. FAO (2012) The state of world fisheries and aquaculture. FAO Fisheries and Aquaculture Department.

4. FAO (2014) The state of world fisheries and aquaculture: Opportunities and challenges. Food and Aquaculture Organization of the United Nations, Rome.

5. Lende SR, Mahida PJ, Mapwesera H, Chavda G, Rana G, et al. (2014) Prospects of tilapia farming in Gujarat region. Indian Farmer 1: 33-37.

6. Plumb JA (1999) Health maintenance and principal microbial diseases of cultured fishes. lowa State University Press, Ames, lowa.

7. Pradeepa PJ, Suebsing R, Sirthammajak S, Kampeera J, Jitrakorna S, et al (2016) Evidence of vertical transmission and tissue tropism of Streptococcosis from naturally infected red tilapia (Oreochromis spp.). Aquaculture Reports 3 : 58-66.

8. Aoki T (1999) Motile aeromonads (Aeromonas hydrophila). Fish Diseases and Disorders. CABI Publishing, Wallingford, UK

9. Austin B, Austin DA (2007) Bacterial fish pathogens: Diseases of farmed and wild fish. (3rd edn), Springer-Praxis, Godalming, UK.

10. Romero J, Feijoo CG, Navarrete P (2012) Antibiotics in aquaculture - Use abuse and alternatives. Health and Environment in Aquaculture, Agricultural and Biological Sciences, InTech.

11. Serrano HP (2005) Responsible use of antibiotics in aquaculture. FAO Fisheries Technical Paper. No. 469. FAO, Rome.

12. FDA-CVM (2007) Aquaculture website. FDA-CVM.

13. Bondad-Reantaso MG, Arthur JR, Subasinghe RP (2012) Improving biosecurity through prudent and responsible use of veterinary medicines in aquatic food production. FAO Fisheries and Aquaculture Technical Paper. No. 547. FAO, Rome.

14. FAO (1996) Residues of some veterinary drugs in animals and foods Monographs prepared by the forty-fifth meeting of the Joint FAO/WHO Expert Committee on Food Additives, FAO Food and Nutrition Paper 41/8, FAO, Rome.

15. Abraham TJ, Sarker S, Dash D, Patra A, Adikesavalu H (2017) Chryseobacterium sp. $\mathrm{PLI}_{2}$ and Aeromonas hydrophila co-infection in pacu, Piaractus brachypomus (Cuvier, 1817) fries cultured in West Bengal, India. Aquaculture 473: 223-227.

16. Roberts RJ (2012) Fish pathology (4th edn), Wiley-Blackwell, UK.

17. Bernet D, Schmidt H, Meier W, Burkhardt-Holm P, Wahli T (1999) Histopathology in fish: Proposal for a protocol to assess aquatic pollution. Journal of Fish Diseases 22: 25-34.

18. Duncan DB (1955) Multiple range and multiple ' $F$ ' test. Biometrics 11: 1-42.

19. Bergh O (2007) The dual myths of the healthy wild fish and the unhealthy farmed fish. Diseases of Aquatic Organisms 75: 159-164.

20. Perera RP, Johnson SK, Lewis DH (1997) Epizootiological aspects of Streptococcus iniae affecting tilapia in Texas. Aquaculture 152: 25-33.

21. Soler F, Reja A, Garcia-Rubio L, Miguez MDP, Roncero V (1996) Anatomopathological effect of OTC in tench (Tinca tinca). Toxicology Letters 88: 104.

22. Ghosh R, Homechaudhuri S (2012) Transmission electron microscopic study of renal haemopoietic tissues of Channa punctatus (Bloch) experimentally infected with two species of Aeromonas. Turkish Journal of Zoology 36: 767-774.

23. Laith AR, Najiah M (2013) Aeromonas hydrophila: Antimicrobial susceptibility and histopathology of isolates from diseased catfish, Clarias gariepinus (Burchell). Journal of Aquaculture Research and Development 5: 215. 
Citation: Julinta RB, Abraham TJ, Roy A, Singha J, Dash G, et al. (2017) Histopathology and Wound Healing in Oxytetracycline Treated Oreochromis niloticus (L.) Against Aeromonas hydrophila Intramuscular Challenge. J Aquac Res Development 8: 488. doi: 10.4172/2155-9546.1000488

24. Reda RM, Ibrahim RE, Ahmed EG, El-Bouhy ZM (2013) Effect of oxytetracycline and florfenicol as growth promoters on the health status of cultured Oreochromis niloticus. Journal of Fisheries and Aquatic Sciences 39: 241-248.

25. Svobodova Z, Sudova E, Nepejchalova L, Aervinka S, Vykusova B, et al. (2006) Effects of OTC containing feed on pond ecosystem and health of carp (Cyprinus carpio L.). Acta Veterinaria Brno 75: 571-577.

26. Lio-Po GD, Albright LJ, Alapide-Tendencia EV (1992) Aeromonas hydrophila in the Epizootic Ulcerative Syndrome (EUS) of snakehead, Ophicephalus striatus and catfish, Clarias batrachus: quantitative estimation in natural infection and experimental induction of dermo-muscular necrotic lesion. Diseases in Asian Aquaculture I. Asian Fisheries Society, Manila, Philippines.

27. Agius C, Roberts RJ (2003) Melanomarcophage centers in fish. Journal of Fish Diseases 26: 499-509.

28. Guerra RR, Santos NP, Cecarelli P, Silva JRMC, Hernandez-Blazquez FJ
(2008) Healing of skin wounds in the African catfish Clarias gariepinus. Journal of Fish Biology 73: 572-583.

29. Ottesen $\mathrm{OH}, \mathrm{Amin} \mathrm{AB}$ (2011) Mortality and cellular response in the skin and gills of plaice (Pleuronectes platessa $\mathrm{L}$ ) to parasite and bacteria infection. BulletinEuropean Association of Fish Pathologist 31: 16-22.

30. Ohira Y, Shimizu M, Ura K, Takagi Y (2007) Scale regeneration and calcification in goldfish Carassius auratus: quantitative and morphological processes. Fisheries science 73: 46-54.

31. Ashley LM, Halver JE, Smith RR (1975) Ascorbic acid deficiency in rainbow trout and coho salmon and effects on wound healing. The Pathology of Fishes. University of Wisconsin Press, Madison.

32. Quilhac A, Sire JY (1999) Spreading, proliferation and differentiation of the epidermis after wounding a cichlid fish, Hemichromis bimaculatus. Anatomical Record 254: 435-451. 